\title{
Lexical Connection: Semiterm Grammatical Patterns in Spanish
}

\author{
Carmen López Ferrero \\ Universitat Pompeu Fabra (Barcelona)
}

\begin{abstract}
The aim of this paper is to describe the grammatical patterns of a set of nouns frequently used in Spanish specialized discourse: the so-called semiterms. The following nouns were selected for the study: problema 'problem', resultado 'result', motivo 'motive/reason', razón 'reason', and consecuencia 'consequence'. Apart from designating specialized concepts in different fields, they can be used to provide structure, introduce information into the text, and act as lexical connectors.

The grammatical and lexicographical description of these semiterms is compared with the results provided by consulting the Corpus de Referencia del Español Actual (CREA) database of the Real Academia Española in three thematic fields: Science and Technology, Economics and Finance, and Law. The results of the research highlight three specific patterns of use for the semiterms in specialized texts, placing particular emphasis on the constructions that contribute to the texture of discourse. It is proposed that these patterns should be incorporated into dictionaries of use (codifiers) as lexicographical data that may enrich the information given about these nouns, whose meanings are clearly diffuse.
\end{abstract}

Keywords: Vocabulary; Spanish; Grammatical pattern; Connection; Specialized Discourse; Corpora.

\section{Introduction: the study of grammatical patterns}

As Francis (1991) pointed out, lexical items are not equally distributed throughout the functional grammatical categories but rather tend to occur in certain linguistic contexts. In fact, certain nouns tend to be used as subjects rather than objects, or vice versa, and others tend to be found in prepositional clauses. Corpus linguistic analysis reveals productive patterns of use of the words in context (Sinclair 1991; Partington 1996; Hunston and Francis 1999; Hanks 2004).

Grammatical patterns have been analyzed from different points of view and different methodologies in corpus studies examining frequent language expressions in texts. For this reason, the terms used to refer to phraseological uses vary depending on the applied criteria -semantic, syntactic, lexical, functional- to characterize them. Wray and Perkins (2000:3) summarize this terminological variation in the following table 1 of R. Moon (1998):

Table 1. Terms used in the reference works to describe formulaic sequences

\begin{tabular}{|c|c|c|}
\hline Amalgams & Gambits & Preassembled speech \\
\hline Automatic & Gestalt & Prefabricated routines and \\
\hline Chumks & Holistie & patterms \\
\hline Clichés & Holophrases & Ready-made expressions \\
\hline Co-ordinate constructions & Idiomatic & Ready-made utterances \\
\hline Collocations & Idioms & Rote \\
\hline Composites & Irregular & Routine formulae \\
\hline Conventionalized forms & Lexicalfised) phrases & Sehemata \\
\hline FEIs ${ }^{2}$ & Lexicalised sefitence stems & Semi-preconstructed phrases \\
\hline Fixed expressions & Multiword units & that constifute single choices \\
\hline Formulaic language & Non-compositional & Sentence builders \\
\hline Formulaic specch & Non-computational & Stable and familiar expressions \\
\hline Formulasformulae & Non-productive & with specialized sobsenses \\
\hline Fossilized forms & Petrification & Synthetic \\
\hline Frozen phrases & Praxons & Unanalysed chunks of speech \\
\hline
\end{tabular}


I choose the term grammatical patterns ('prefabricated routines and patterns') to highlight the following four basic features of the object of the present study:

i) they constitute specific syntactic structures, for example, copulative structures such as 'it is NP that', relative clauses as 'what P is that', and impersonal constructions such as 'it is Ved that' (Oakey 2002; Hyland 2004);

ii) the lexical items that fill them tend to belong to a particular semantic type;

iii) they exhibit some degree of phraseologization and conventionalization (Hunston 2001) - in fact, a pattern is a repeated discourse insofar as it is a way of saying things that is preferred by a community of speakers in certain contexts; and

iv) they perform a pragmatic function: they either act as discourse markers that indicate the text organization or are related to interactive functions (Simpson 2004). It is specifically this pragmatic function of patterns as discourse markers that accounts for their high frequency of use (cf. Nattinger and DeCarrico 1992; Swales 2001; Flowerdew 2002 and 2003).

The term grammatical patterns shows the relationship between lexical items, syntax and pragmatic function in texts for specific purposes, as table 2 exemplifies:

Table 2. Example of grammatical pattern with focalization function

\begin{tabular}{|l|l|}
\hline Grammatical pattern & \multicolumn{1}{c|}{ Det N be that } \\
\hline $\begin{array}{c}\text { Lexical items that } \\
\text { cover N } \\
\text { (semantic classes) }\end{array}$ & $\begin{array}{l}\text { problema ('problem'), resultado ('result'), conclusion ('conclusion'), } \\
\text { razón ('reason'), respuesta ('answer'), consecuencia ('consequence'), } \\
\text { propuesta ('proposal'), ventaja ('advantge'), diferencia ('difference') }\end{array}$ \\
\hline Pragmatic function & Focalization: signal of informational focus \\
\hline Discourse genre & Scientific article \\
\hline
\end{tabular}

Hunston and Francis (1999: 3) define pattern as follows:

[...] a pattern is a phraseology frequently associated with (a sense of) a word, particularly in terms of the prepositions, groups, and clauses that follow the word. Patterns and lexis are mutually dependent, in that each pattern occurs with a restricted set of lexical units, and each lexical item occurs with a restricted set of patterns.

Although many reference works describe grammatical patterns in professional and academic discourses in English with the tools provided by corpus linguistics (e.g. Biber 1996 and 2005; Granger 1998; Hunston 2002; Trosborg and Flyvholm Jørgensen 2005), such studies have not yet been carried out in Spanish. This paper aims to contribute to progress in this field, describing the patterns of use of a particular set of Spanish nouns as semiterms in specific communication contexts.

In English, it has been pointed out that sub-technical vocabulary -in this paper semiterms-(factor, system, structure, method, function, for example) is problematic in specialized second language acquisition and in reading comprehension of specific texts (Baker 1988; Martinez 1994). Three main reasons explain this difficulty: semiterms refer to abstract notions (Baker 1988; Blaisten et al. 1998; Schmid 2000); they are often discipline and genre-dependent: what is suitable in one discipline or in one genre may not be suitable in another (Martinez 1994; Blaisten et al. 1998); consequently, they are polysemous. These nouns, not identified as specialized or general, are assumed to have potentially significant role in structuring the writer's argument: they are clues in text 
production. Therefore, their interpretation requires sophisticated processing strategies, as Ivanič (1991) has also emphasized.

The present paper is based on the results obtained in a previous study (López Ferrero 2007) focusing on words used in two grammatical patterns that indicate the Theme (given information) or Focus (relevant information) in specialized texts: for instance, the noun problema in structures of the type el problema es que 'the problem is that' ${ }^{1}$. Using corpus linguistic methodology, I compared the lexical items selected for these patterns in a set of specialized and general texts. This previous study revealed that, in specialized texts, argumentative discourse is organized by thematizing nouns such as conclusión 'conclusion', razón 'reason', and consecuencia 'consequence', and that the informative content of these lexical items is positively emphasized by adjectives such as fundamental 'important/crucial', importante 'important', indiscutible 'indisputable', and interesante 'interesting'. Those grammatical patterns were found to be different in general texts: the nouns more frequently used to express the Theme or the Focus in a copulative structure such as the detailed above were not semiterms but very semantically empty nouns such as thing, idea, matter or point, for example. Therefore, those nouns were not related with the categories of argumentative discourse, as highlighted in the case of specialized corpus; they were thus not characterized as semiterms.

\section{Vocabulary analyzed: semiterms}

The five nouns selected for the present analysis (problema 'problem', resultado 'result', motivo 'motive/reason', razón 'reason', and consecuencia 'consequence') can be considered semiterms ${ }^{2}$ (Blaisten et al. 1998) because they are used in everyday language but they may also adopt a terminological value when used in specialized texts and thus contribute to the transmission of knowledge (Cabré 1999; Ciapuscio 2003). The criterion to select these five semiterms is their frequency of shared uses in specialized discourse: in the abovementioned study (López Ferrero 2007) they were found to be the more frequent nouns in emphatic syntactic constructions, that is to say, in Theme or Focus copulative structures used in different thematic fields; for example: Esa es la razón por la que... / Ese es el motivo por el que 'That is the reason why...'. In these functions recurrent nouns which signal stress parts of an expository-argumentative Spanish discourse are the five here analyzed: problema, resultado, motivo, razón, consecuencia. They have some special meaning features which allow them to be used in a wide variety of subject areas.

From a semantic point of view, semiterms are generally relative nouns, that is to say, they require a prepositional phrase (de + noun phrase) as an argument which specifies a type of relationship, as in la razón de su trabajo 'the reason for his/her work' or la consecuencia de su descubrimiento 'the consequence of his/her findings'.

Additionally, the words analyzed herein can also be considered as lexical proforms (Halliday and Hasan 1976) because they constitute general words whose meaning is only specified by reference to preceding discourse, like cosa 'thing', asunto 'issue, matter', tema 'topic' and hecho 'fact' (Swales 2001). They thus have a cohesive function and play a role in structuring discourse.

According to Scott (2001), the scope of use of these nouns ranges from the local level of the clause or sentence, as semiterms that designate key concepts in the text, to the overall level of discourse, at which they signal parts of an argumentative structure. Swales (2001) characterizes the macrotextual uses of these words in oral academic discourse as discussive uses, and describes them as lexical items that refer to the elements of a discussion, in which they present the argumentative point. 


\section{Research objectives}

As for the use of nouns in context, in this study I attempt to:

1. Analyze the grammatical patterns of a representative group of five Spanish semiterms in a corpus of specialized texts from different fields.

2. Determine the scope of use of these words in discourse: that is, whether they are used to designate key concepts in specific fields at the local level of the clause or sentence, or as lexical connectors that help to structure and organize globally the text.

3. Relate different levels of text analysis: the informative structure of the sentence (in terms of Theme and Rheme), the syntactic level, and the lexical level, on the basis of the patterns of use observed.

4. Consider the implications of the data provided by discourse and corpus analysis for grammatical and lexicographic description and for educational purposes.

\section{Methodology of the study}

The texts used for the present study were obtained from the Corpus de Referencia del Español Actual (CREA), which is accessible at the Real Academia Española website (www.rae.es). The corpus was selected according to the following three criteria (see the appendix at the end of the paper):
a) Medium: Books
b) Geography: Spain
c) Fields: $\quad$ Science and Technology (code 115)
Economics and Finance (code 305)
Law (code 317)

The criterion to study the semiterms in three different fields was to observe if their use in context varies depending on each specific field, that is to say, if they present different grammatical patterns according to the subject area where they are used. Thus three well-established specialized disciplines have been considered: one from scientific branches -Science and Technology-, another from human disciplines -Law- and the third one from social sciences -Economics and Finance-.

In the three thematic fields only books as texts were included for the present study, in order to analyze semiterms in a formal specialized written register. The corpus of texts studied according to this register criterion are all written by leading Spanish researchers in each field: see the list of the selected books for the corpus in table 3, with the total word count for each field.

Table 3. Corpus of texts studied

\begin{tabular}{|c|c|c|}
\hline Field & Documents & $\begin{array}{l}\text { No. of } \\
\text { words }\end{array}$ \\
\hline \multirow{3}{*}{$\begin{array}{l}\text { Science and } \\
\text { Technology }\end{array}$} & $\begin{array}{l}1 \text { QUINTANILLA, Miguel Ángel and SANCHEZ RON, José M }{ }^{\mathrm{a}} \\
\text { (1997). Ciencia, tecnología y sociedad - Science, technology } \\
\text { and society: Madrid: Santillana }\end{array}$ & 71,566 \\
\hline & $\begin{array}{l}2 \text { SÁNCHEZ Ron, José Ma (1995). La ciencia, su estructura y su } \\
\quad \text { futuro - Science, its structure and its future. Madrid: Debate. }\end{array}$ & 22,043 \\
\hline & $\begin{array}{l}3 \text { VERNET, Juan (1981). La originalidad de la Ciencia Árabe } \\
\text { (Historia de la Ciencia Árabe) - The originality of Arab } \\
\text { Science (History of Arab Science). Madrid: RACEFN }\end{array}$ & 7,617 \\
\hline
\end{tabular}


López Ferrero, Carmen (2012). "Lexical Connection: Semiterm Grammatical Patterns in Spanish", Applied Linguistics, n³3(4), Oxford University Press, pp. 428-449.

1 AlbarRacín, Jesús (1991). La economía de mercado - The 99,721

Economics market economy. Madrid: Trotta, 1994.

and Finance

2 EstefaníA, Joaquín (1995). La nueva economía - The new economy. Madrid: Debate.

3 TAMAMEs, Ramón (1992). Curso de Economía - Economics course, Madrid: Alhambra Longman

23,502

131,361

TOTAL:

$\mathbf{2 5 4 , 5 8 4}$

1 ATIENZA, Manuel (1993). Tras la justicia. Una introducción al

76,943 derecho y al razonamiento jurídico - In search of justice. An introduction to law and legal reasoning. Barcelona: Ariel

2 LÓPEZ GARRIDO, Diego (1991). El derecho de asilo - The right to asylum. Madrid: Trotta.

3 PECES-BARBA, Gregorio (1983). Introducción a la filosofía del derecho - Introduction to the philosophy of law. Madrid: Debate.

4 SÁnchez Almeida, Carlos (2002). La ley de Internet. Régimen jurídico de los Servicios de la Sociedad de la Información y Comercio Electrónico - Internet law. Legal regime of the information and e-commerce society services. Barcelona: SERVIDOC

5 Various Authors (2002). Ley 34/2002 de 11 de julio, de Servicios de la Sociedad de la Información y de Comercio Electrónico - Law 34/2002 dated 11 July, on information and e-commerce society services. Barcelona: SERVIDOC

6 Various Authors (2002). Directiva 2000/31/CE del Parlamento Europeo y del Consejo (de 8 de junio de 2000) [Ley de Internet] - Guidelines 2000/31/EC of the European Parliament and Council (8 June 2000) [Internet Law]. Barcelona: SERVIDOC

7 Various Authors (2002) Código Penal (extracto). Delitos de posible comisión mediante medios informáticos (La ley de Internet) - Penal Code (extract). Offences that can be committed through computerized media (Internet Law). Barcelona: SERVIDOC

The sample of documents in each field is considered representative due to the variety of authors: the fact that different specialists -each of them with their own written style, more personal in a book than in a scientific article- coincide in the semiterms patterns of use proves that these uses are typical Spanish constructions where the studied nouns appear. Moreover, the samples in the CREA corpus have been accurately selected by the Real Academia Española as standard examples of contemporary use of Spanish language.

In order to compare findings, the results are presented in percentages, since the total number of words for each field is different (approximately 100,000 for Science and Technology, 250,000 for Economics and Finance, and 330,000 for Law).

The most frequent combination patterns of the semiterms studied were established for each field by analyzing the first 200 occurrences of each word ${ }^{3}$. Table 4 presents the 
López Ferrero, Carmen (2012). "Lexical Connection: Semiterm Grammatical Patterns in Spanish", Applied Linguistics, n³3(4), Oxford University Press, pp. 428-449.

results of an initial corpus search, with the number of cases analyzed indicated for each lexical item.

Table 4. Gross results of the CREA search: frequency of occurrence ${ }^{4}$

\begin{tabular}{|lccc|}
\hline & $\begin{array}{c}\text { Science and } \\
\text { Technology }\end{array}$ & Economics and Finance & Law \\
\hline $\begin{array}{l}\text { problema* } \\
\text { 'problem' }\end{array}$ & $\begin{array}{c}149 \text { cases in } 3 \\
\text { documents }\end{array}$ & $\begin{array}{c}223 \text { cases in 3 documents } \\
=>200 \text { cases in 3 } \\
\text { documents }\end{array}$ & $\begin{array}{c}318 \text { cases in 5 } \\
\text { documents }=> \\
200 \text { cases in } 4 \\
\text { documents }\end{array}$ \\
\hline $\begin{array}{l}\text { resultado* } \\
\text { 'result' }\end{array}$ & $\begin{array}{c}112 \text { cases in 3 } \\
\text { documents }\end{array}$ & 119 cases in 3 documents & $\begin{array}{c}65 \text { cases in 5 } \\
\text { documents }\end{array}$ \\
\hline $\begin{array}{l}\text { motivo* } \\
\text { 'motive' }\end{array}$ & $\begin{array}{c}19 \text { cases in 2 } \\
\text { documents }\end{array}$ & 6 cases in 3 documents & $\begin{array}{c}105 \text { cases in 7 } \\
\text { documents }\end{array}$ \\
\hline $\begin{array}{l}\text { razón/rezones } \\
\text { 'reason/ }\end{array}$ & $\begin{array}{c}29 \text { cases in 3 } \\
\text { documents }\end{array}$ & 91 cases in 3 documents & $\begin{array}{c}364 \text { cases in 7 } \\
\text { documents }=>200 \\
\text { cases in 7 documents }\end{array}$ \\
\hline $\begin{array}{l}\text { consecuencia* } \\
\text { 'consequence' }\end{array}$ & $\begin{array}{c}88 \text { cases in 3 } \\
\text { documents }\end{array}$ & 191 cases in 3 documents & $\begin{array}{c}209 \text { cases in 5 } \\
\text { documents }=>200 \\
\text { cases }\end{array}$ \\
\hline
\end{tabular}

In the following sections, I will present the patterns of use of semiterms emerging from the corpus analysis. I will also propose the peculiarities observed for each specialized field. Finally, significant contributions from the results will be highlighted in comparison with other previous studies on semiterms.

\section{Qualitative findings}

Due to lack of space, only sample concordances of three of the above semiterms (problema, resultado and razón) are presented below, as the CREA database shows them in its information technology: 
López Ferrero, Carmen (2012). "Lexical Connection: Semiterm Grammatical Patterns in Spanish", Applied Linguistics, n³3(4), Oxford University Press, pp. 428-449.

Figure 1. Uses of the problema(s) item in Law documents

\section{REAL ACADEMIA ESPAÑOLA}

$\mathrm{H}^{\circ}$ COHCORDAHCIA

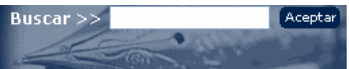

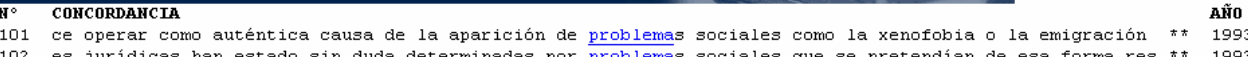
102 es juridicas han estado sin duda determinadas por problemas sociales que se pretendían de esa forma res $t * 199$ 103 te, de maner distinta: para los legisladores, el problema a resolver es el de cúndo, de qué manera, $c$ * 1993 等 105 que han tenido lugar y que configuran un caso - un problema- concreto y determinado. De alguna forma, po *t 1993 106 on las instrucciones ahi contenidas, los diversos problemas que plantea su puesta en práctica. En los a $* 1993$ 107 del Derecho? Pero antes de abordar propiamente el problema de la legislación, conviene hacer algunas in $* * 1993$ 108 co después, pero que mostraba la existencia de un problema social que exigía una intervención legislati $\hbar$ * 1993 109 erecho constitucional o el Derecho penal. Pero el problema es que no es nada fácil precisar en qué cons $*$ * 1993 110 s particulares-y las de Derecho público. Pero el problema es que no parece haber ninguna institución $j$ * 1993 111 de subordinación que presupone este criter10. El problema de la distinción entre Derecho público y Der *t 1993 112 onceptos), pero hay que reconocer tamblen que los problemas de vaguedad son, en general, más difíciles ** 1993 113 za de la medida para casos en que "pueden existir problemas de indole humana trascendente", por ejemplo

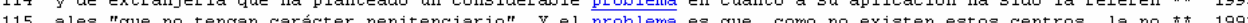
116 in 117 alcancen los objetivos previstos. El otro tipo de problema es que esos objetivos sociales pueden, por $d$ t 1993 118 jetivos a hora debemos considerar el otro tipo de problem a que se hizo referencis al comienzo del apa * 1993 119 Ley de extranjería plantea, por cierto, no pocos problemas de tipo moral que van más allá de la adecua $\hbar$ t 1993 120 u contenido, derechos de configuración legal." El problema, entonces, radica en fijar hasta qué punto $e$ * 1993 121 titucional contribuyó sólo en parte a resolver el problema, es por estas dos razones. En primer lugar, t* 1993 122 uencia -como hemos visto en capítulos anteriores- problemas de ética que no podrían resolverse apelando $t * 1993$ 123 cerca de la del legislador que de la del juez; el problema que debe resolver el abogado -y en cuyo cont \#\# 1993 124 verse cuando se compara, a propósito de un mismo problema normativo -el que planteaba el artículo 34.2 t* 1993
125 e énfasis), podemos pasar ahora al último de los problemas a tratar: ceómo se relacionan ambos tipos d ${ }^{*}$ 1993

\section{REAL ACADEMIA ESPAÑOLA} $\begin{array}{llll}\text { COHCORDAHCIA } & \text { AÑ } \\ \text { ómica, sanitaria, educativa- que han mostrado los resultados científicos obtenidos especialmente durant } \hbar * & 1995\end{array}$ 3 Unidos durante la segunda guerra mundial. Y los resultados, a todas luces satisfactorios desde el pun $* 1995$ de se ling, qú alué se empleá yun quest 1995 1 an a iguar si su hijo padecería el mismo trastorno. El resultado fue positivo, pero la mujer decidí́ continu to 1995 ón de esperma y sostiene que la fiabilidad de sus resultados es en torno al 80 por 100 . Da idea de la st to 1995 la tecnología estrechemente relacionadas con los resultados obtenidos por los cientificos han tenido $m$ th 1995 ión no dependen excesivamente, en general, de los resultados de la investigación científica o de la tec t* 1995 iterarios, artísticos, científicos o técnicos. Fl resultado de todo ello es que cada vez resulta más di *t 1997 una parte importante de la actividad social y sus resultados contribuyen en gran medida a configurar el $\hbar$ t 1997 sistemas de regulación del tráfico que incorporan resultados de la investigación y de la tecnología más t⿱ 1997 onocimiento basado en la experiencia práctica. El resultado de las actividades de desarrollo es por 10 th 1997 que entendemos por conocimiento científico es el resultado de un largo proceso histórico en el que se $\hbar$ t 1997 la realidad para conseguir de forma eficiente un resultado que se considera valioso. Las reglas téenic ** 1997 más del conocimiento científico, se inventan como resultado de un proceso sistemático de I+D y evolucio $\hbar$ t 199 ? os concretos para conseguir de forma eficiente un resultado que se considera valioso. 4.2 INVENCión E I औ 1997 tores: $10 s$ que afectan al valor o utilidad de los resultados del sistema técnico y los que afectan a la $\hbar$ * 1997 pudiera parecer, el juicio sobre el valor de los resultados de una tecnica o sobre su eficacia y efici ** 1997 ilidad de un sistema tecnico, sus objetivos y sus resultados. Por eso se producen a veces duras controv $\hbar^{*} 1997$ cnologico debe definir claranente sus objetivos y resultados, los criterios de valoracion en que se bas tht tividades de investigación y a la difusion de sus resultados: las academias, las sociedades cientificas ${ }^{*} 1997$ empresa colectiva que requiere de intercambio de resultados. No hay, por consiguiente, ciencia sin med *t 1997

Ir arriba Pantalla: 1 de 5 . Siquiente $1 \underline{2} \underline{3} \underline{4} \underline{\text { Ver párrafos }}$

Nueva consulta: CREA CORDE Nómina de autores y obras Ayuda. 
Figure 3. Uses of the razón item in Law documents

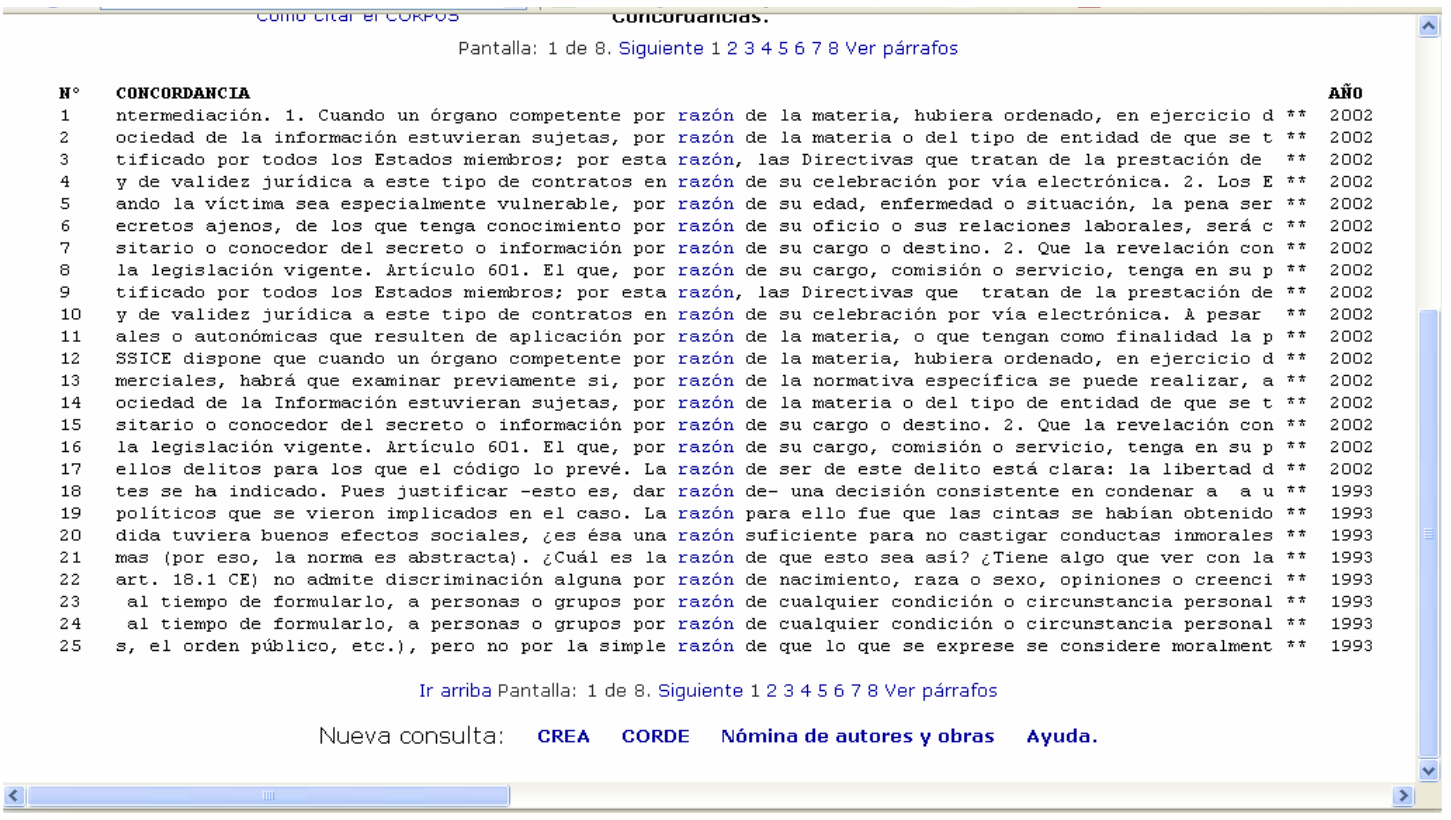

Figure 4. Uses of the razones item in Economics and Finance documents

Fiğ Sábado, 16 de diciembre de 2006

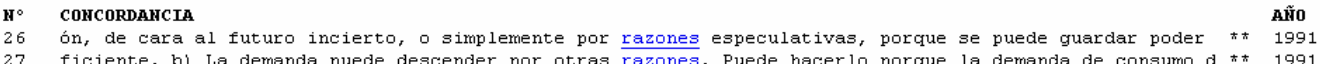
ficiente. b) La demanda puede descender por otras razones. Puede hacerlo porque la demanda de consumo d $\hbar \hbar 1991$ e los precios de producción medidos en dinero por razones muy diversas. Las fluctuaciones erráticas que $\hbar$ t 1991 es, personas que libremente se ven obligadas, por razones economicas, a vender su fuerza de trabajo a c * 1991 que la capacidad productiva, el empresar 1o tendra razones mas que suficientes para no realizar la inver $t^{*} 1991$ resados en un aumento de la productividad por dos razones fundamentales. En primer lugar, el aumento de $t * 199$ reficios menores que la plusvalía. Estas lo tazones fundamentes. En primer lugar, el aumento de $t \pi 1991$ de la fase expansiva a la recesiva se produce por razones internas, pero la salida de la fase recesiva $* *$ t 1991 de la fase exan de los precios de producción en dinero por razones muy cuenta y medio de pago en cada uno de ellos. Hay razones objetivas e históricas para que así hava ocur $\hbar$. 1991 $s$ de desarrollo capitalista, etc. Por todas estas razones, desde un principio, parte de la moneda metál $\hbar \hbar$ t 199 uperávit). Evidentemente, puede disminuir por las razones contrarias. El objeto de la política monetari $t * 199$ amás conocida. Ya se han explicado cuáles son las razones de que así ocurriera. Sin embargo, en la onda $\hbar$ t 1991 evita el saneamiento del aparato productivo. Por razones similares, en la expansión permite que se 11 e $\hbar$ t 1991 ts públicos no es deseado por el capital, por dos razones que están relacionadas. En primer lugar, el a tt 1991 - que agravaría el déficit público. Estas son las razones reales de que los organismos internacionales * 1991 nflación permanente no deseada. También por estas razones se ha propugnado la reducción del déficit púb t* 1991 aría una elevación de los precios. Por las mismas razones, la inversión no crecería ante el aumento de $\hbar^{*} 1991$ la misma. Pero la clase dirigente tuvo poderosas razones para adoptarla. Por un lado, la ideología en $\hbar^{\hbar} 1991$ n capitán y una tripulación más ignorantes de las razones de su mala fortuna o más impotentes para hace *\# 1991

\footnotetext{
Ir arriba pantalla: 2 de 2.12 ver párrafos
}

Nueva consulta: CREA CORDE Nómina de autores y obras Avuda. 
Concordances in figures 1, 2, 3 and 4 give indication of typical patterns of use: they are constructions repeated in the three thematic fields books written by different authors. As I have defined in the introduction of this paper, a pattern is a repeated discourse insofar as it is a way of saying things that is preferred by a community of speakers or writers in certain contexts.

Three patterns of use were identified ${ }^{5}$ in the corpus analyzed: a terminological pattern $(\S 5.1)$, a metadiscursive pattern $(\S 5.2)$ and a grammaticalized locution pattern $(\S 5.3)$. The specific contributions of the present paper are related to the terminological pattern (see figures 1,2 and 4) and the grammaticalized locutions (see figure 2 and specially figure 3), in contrast with studies referring to the English language, as it will be pointed out in the next sections.

\subsection{Terminological pattern}

In examples (1) to (4), which are selected occurrences from the CREA corpus, the nouns highlighted in bold type ${ }^{6}$ are used with a terminological value to refer to key concepts in each discipline: problemas estructurales 'structural problems' and razón social 'company name' in examples (1) and (2) from Economics; consecuencias penales 'penal consequences', resultado lesivo 'harmful result', motivos de conciencia 'reasons of conscience' in (3) and (4) from the field of Law; and resultados científicos 'scientific results' in (4) from Science and Technology:

(1) La retirada de Chile, desde el golpe de Estado de Pinochet, los problemas estructurales de Bolivia, las fricciones entre Perú y Ecuador por cuestiones fronterizas, y otras muchas situaciones, han hecho difícil la vida del Grupo Andino. (Tamames, Ramón. 1992. Curso de Economía. Madrid: Alhambra Longman, p. 325)

'Chile's withdrawal after Pinochet's coup d'état, Bolivia's structural problems, the friction between Peru and Ecuador due to border disputes and many other situations made the Grupo Andino's life difficult.'

(2) Las sociedades mercantiles, que son, con mucho, las más frecuentes, se dividen en:

1. Sociedad colectiva [...]. Su razón social se forma generalmente por el nombre de uno o de varios de sus socios. (Tamames, Ramón 1992. Curso de Economía. Madrid: Alhambra Longman, p. 93)

'Corporations, which are by far the most common type of company, are divided into:

1. Partnership [...]. The company name generally consists of the name of one or several of its partners.'

(3) Las consecuencias penales serán distintas en función del tipo de virus:

Los virus inocuos es muy discutible que puedan perseguirse, puesto que es fundamental que exista un resultado lesivo para que exista delito. (Sánchez Almeida, Carlos 2002. La ley de Internet. Régimen jurídico de los Servicios de la Sociedad de la Información y Comercio. Barcelona: SERVIDOC, p. 188)

'The penal consequences will vary according to the type of virus:

It is debatable whether innocuous viruses can be prosecuted, since it is fundamental that there should be a harmful result for there to be an offence.'

(4) [...] si las leyes democráticas y constitucionales de un verdadero Estado de Derecho pueden no acatarse por motivos de conciencia, también, y por los mismos motivos, podrán dejar de acatarse las sentencias de los tribunales [...] 
(Atienza, Manuel. 1993. Tras la justicia. Una introducción al derecho y al razonamiento jurídico. Barcelona: Ariel)

'[...] if the democratic and constitutional laws of a true state that follows the rule of law may be contravened by reasons of conscience, the judgments given by the court may be contravened too for the same reasons.'

(5) Jamás se debe olvidar que sin ideas, teorías, experimentos, sin resultados científicos, nunca habrá ciencia. (Quintanilla, Miguel Ángel; Sánchez Ron, José M. 1997. Ciencia, tecnología y sociedad. Madrid: Santillana, p. 38)

'It should never be forgotten that without ideas, theories, experiments, without scientific results, there will never be science.'

The high frequency of the Spanish pattern semiterm (problema, razón, etc.) plus specific adjective (estructural, social, etc.) or prepositional phrase (de inflación, de la investigación, de conciencia), illustrated in (1) to (5) suggests that these lexical combinations are highly productive (cf. Bosque 2004). Semiterm and relational adjective form a multilexemic terminological pattern to designate notions pertaining to a specialized field.

Moreover, the fact that the semiterms studied are complemented is an indication of their low semantic value. They can therefore be described as light words which constitute the basis for multilexemic terms employed in each field, in the form of nominal locutions ${ }^{7}$. These phrases are frequently used in plural in the CREA corpus:

Table 5. Terminological Pattern: semiterm [frequently plural] + relational adjective or prepositional phrase

\begin{tabular}{|c|c|c|}
\hline Science and Technology & Economics and Finance & Law \\
\hline $\begin{array}{l}\text { problemas científicos } \\
\text { 'scientific problems' }\end{array}$ & $\begin{array}{l}\text { problemas económicos 'economic } \\
\text { problems' }\end{array}$ & $\begin{array}{l}\text { problemas jurídicos } \\
\text { 'legal problems' }\end{array}$ \\
\hline $\begin{array}{l}\text { problemas técnicos } \\
\text { 'technical problems' }\end{array}$ & $\begin{array}{l}\text { problemas estructurales } \\
\text { 'structural problems' }\end{array}$ & $\begin{array}{l}\text { problemas de tipo normativo } \\
\text { 'problems of a legal nature' }\end{array}$ \\
\hline $\begin{array}{l}\text { resultados de la actividad } \\
\text { científica y tecnolóqica }\end{array}$ & resultado final del ejercicio & resultado jurídico \\
\hline $\begin{array}{l}\text { 'results of scientific and } \\
\text { technological activity' }\end{array}$ & $\begin{array}{l}\text { resultados de la productividad } \\
\text { 'results of productivity' }\end{array}$ & $\begin{array}{l}\text { resultado lesivo } \\
\text { 'harmful result' }\end{array}$ \\
\hline $\begin{array}{l}\text { resultados de la investigación } \\
\text { 'research results' }\end{array}$ & $\begin{array}{l}\text { motivos económicos } \\
\text { 'economic reasons' }\end{array}$ & $\begin{array}{l}\text { motivo del obrar } \\
\text { 'reason for acting', }\end{array}$ \\
\hline $\begin{array}{l}\text { resultados científicos } \\
\text { 'scientific results' }\end{array}$ & $\begin{array}{l}\text { consecuencias económicas } \\
\text { 'fiscal consequences' }\end{array}$ & $\begin{array}{l}\text { motivos de conciencia 'reasons of } \\
\text { conscience' }\end{array}$ \\
\hline & $\begin{array}{l}\text { razones económicas } \\
\text { 'economic reasons' }\end{array}$ & $\begin{array}{l}\text { consecuencias penales } \\
\text { 'penal consequences' }\end{array}$ \\
\hline & $\begin{array}{l}\text { razones estructurales } \\
\text { 'structural reasons' }\end{array}$ & $\begin{array}{l}\text { consecuencias normativas } \\
\text { 'consequences of the law' }\end{array}$ \\
\hline & etc. & $\begin{array}{l}\text { razón de Estado } \\
\text { 'reason of State' }\end{array}$ \\
\hline & & $\begin{array}{l}\text { razón práctica } \\
\text { 'practical reason', etc. }\end{array}$ \\
\hline
\end{tabular}


Studies about English semiterms have focussed on how their full meaning is 'realized' elsewhere in the text, either within the same clause or across clauses. They do not focus on those nouns which are not realized in the text, i.e. they are exophoric, relying on background knowledge for realization of the full meaning. Uses of Spanish semiterms in the corpus analyzed in this paper show how the exophoric type can function as part of multi-word technical terms. This function of semiterms has not been pointed out in previous studies.

Many of the terminological uses in the corpus studied are included in specialized dictionaries, in which these words are defined as terms within specific fields. For example, the word problema is defined in Vocabulario Científico y Técnico (1996), 3rd ed., of the Spanish Real Academia de Ciencias Exactas, Físicas y Naturales as the 'planteamiento de una situación cuya respuesta desconocida debe obtenerse a través de métodos científicos' ('expression of a situation to which the response is unknown and must be obtained by scientific methods'). Another example is that of resultado, which is defined in the Spanish Diccionario Espasa Economía y Negocios, A. Andersen, 1998, 3rd ed., as 'beneficio o pérdida que arroja una sociedad al final de cada ejercicio económico y que se obtiene deduciendo de todos los ingresos los gastos correspondientes al mismo periodo' ('the profit or loss of a company at the end of each financial period obtained by deducting the expenditure for the period from the total income received'). These specialized meanings are not usually included in general dictionaries of Spanish, and when they are the specific meaning is not always indicated as technical (this is the case, for example, of problema).

\subsection{Metadiscursive pattern}

Example (6) illustrates another type of construction that also showed a high frequency of use in the corpus studied:

(6) Finalmente, el argumento de evitar que se abran paso 'razones de Estado', indicado en $2.2 \mathrm{H}$, no me parece tampoco convincente por dos razones. Una es que el argumento es en sí mismo débil, [...]. La otra razón es que el argumento está mal dirigido, en el sentido de que el destinatario del mismo sería, en todo caso, el Gobierno, pero no los jueces. (Atienza, Manuel 1993. Tras la justicia. Una introducción al derecho y al razonamiento jurídico. Barcelona: Ariel, p. 114)

'Finally, the argument of preventing 'reasons of State' from arising, as indicated in $2.2 \mathrm{H}$, does not convince me either for two reasons. One is that the argument is weak in itself [...]. The other reason is that the argument is misdirected in the sense that its addressee would be the Government rather than the judges.'

At the beginning of (6), the word razones in razones de Estado has a terminological value and designates a specialized concept. On the other hand, the word razones in por dos razones serves to organize the discourse, anticipating the two-part argumentative structure that supports the main statement. It can therefore be said to have a deictic-cataphoric function (Santos Río 2003) because it refers to linguistic elements that come later in the text. The deictic function is in this case a form of textual deixis, with text being interpreted as a space that can be referred to by means of linguistic resources.

Let us now see the metadiscursive use of other lexical items (problema, resultado and consecuencia) illustrated in the following examples (7) to (9) below: 
(7) El peligro de que los estudios hereditarios puedan ser utilizados con intenciones políticas no es producto de la imaginación de aquellos que ven con ojos críticos estas investigaciones. [...]

EI gran problema es, sin embargo, que existen serias dudas sobre el rigor, científico, metodológico, de muchas de las investigaciones que se presentan como concluyentes. (Sánchez Ron, José M. 1995. La ciencia, su estructura y su futuro. Madrid: Debate, pp. 67-68)

'The danger that hereditary studies may be used for political purposes is not a figment of the imagination of those who are critical of such studies. [...]

The main problem is, however, that there are serious doubts about the scientific and methodological rigor of many studies that are presented as being conclusive.'

(8) El resultado es que el gobierno crece demasiado, y sus operaciones se vuelven cada vez más costosas. (Tamames, Ramón 1992. Curso de Economía. Madrid: Alhambra Longman)

The result is that the government grows too much, and its operations become increasingly costly.'

(9) La mayoría de los especialistas están de acuerdo, de hecho, en que, en todo caso, los nuevos empleos que se creen tendrán, en general, un nivel de cualificación más alto que el de los empleos que se destruyan. De ahí se derivan consecuencias importantes: la necesidad de mejorar los niveles de educación y de cualificación profesional, etc. (Quintanilla, Miguel Ángel; Sánchez Ron, José M. 1997. Ciencia, tecnología y sociedad. Madrid: Santillana)

'Most specialists agree, in fact, that newly created jobs will generally have a higher level of qualification than the jobs that are destroyed. Hence important consequences are derived: the need to improve the standards of education and professional qualification, etc.'

In order to distinguish the two patterns of use so far identified for the explored nouns, that is to say, the terminological use in examples (1) to (5) and the metadiscursive use in examples (6) to (9), anaphoric completion can be applied as a formal criterion. When used with a terminological value, the lexical items studied do not allow complements of textual anaphora. Thus (question marks in the following examples represent doubtful grammatical uses in Spanish):

(10) ?? razones de Estado de lo dicho "? reasons of State of the aforementioned'

(11) ?? razones tecnológicas de ello "? technological reasons for this' (12) ??
?? pensecuencias penales de ello
consequences of this'

However, when they have a metadiscursive value, they do allow a complement that specifies the anaphoric or cataphoric reference:

(13) por dos razones [en relación con lo dicho] (example 5)

'for two reasons regarding the aforementioned'

(14) el gran problema [de lo mencionado] (example 6)

'the main problem of the aforementioned' 
(15) El resultado [de ello] (example 7) 'the result of this'

(16) De ahí se derivan consecuencias importantes (example 8) 'Hence important consequences are derived'

The metadiscursive meaning of these words is not accounted for in general or specialized Spanish dictionaries. Only in more idiosyncratic dictionaries such as the Diccionario de Partículas (Santos Río 2003) are these discursive values included. In the Diccionario de Partículas these patterns are referred to as 'discourse signalling deicticanaphoric sequences'. According to Santos Río (2003: 572), the absence of the argument complement of a noun phrase in a relative noun like resultado makes it deictic-anaphoric, since the lexical unit refers to a fact or set of facts that have just been mentioned.

The anaphoric function of these nouns thus allows us to determine whether or not they have a metadiscursive use. In metadiscursive patterns, an initial topic either leads to certain consecuencias, problemas or resultados, or it is the origin of certain razones or motivos. Therefore, while in terminological patterns the nouns refer exophorically to a disciplinary concept, in the metadiscursive use they establish a form of textual deixis (Conca et al. 1998) by means of endophoric reference and do not bear a specialized meaning. The function of signalling discourse observed in the problema item has also been highlighted in previous studies that analyzed this semiterm in other fields such as history, academic discourse or engineering (Martinez 1994; Tracy-Ventura et al. 2007; Cortes 2008).

Another textual characteristic of these units is also worth mentioning. When the analyzed nouns are used in a metadiscursive pattern, they are preceded by a full stop, as in (6), or a full stop followed by a new paragraph, as in (7) to (9). In these cases, they act as markers that introduce a pause in the discourse in order to focus on information that needs to be emphasized, and thus fulfil a pragmatic function in the thematic progression of the text. For instance, in (7) the Focus is on the dudas sobre el rigor, científico, metodológico, de muchas de las investigaciones que se presentan como concluyentes; in (9), the Focus is on consecuencias importantes; and in (6) la otra razón indicates the introduction of a new point in the argumentation.

Ivanič (1991) characterized nouns as problem as 'carrier nouns' which can take a noun clause or nominalisation as complement. This complement can be found either in the same sentence, or elsewhere in the discourse. Beyond sentence boundaries carrier nouns operate like pronouns, but they refer to verbal elements: ideas, facts and events rather than objects. Schmid (2000) has also analyzed this function in English semiterms, which he names "shell nouns": they are so relatively unspecific in content that they are used in certain syntactical surroundings which specify their content.

Another criterion that highlights the cohesive nature of forms such as consecuencia or resultado is that suggested by Winter (1978: 45): when used with a metadiscursive value, these nouns cannot be metaphorized because they are already metaphors. ${ }^{8}$ According to Winter, they are fixed metaphors and so they do not work well in comparisons such as (17) and (18) below:

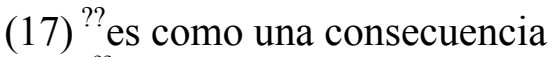

"? it is like a consequence'

(18) ?? es como un resultado

"? it is like a result' 
Analogies such as these only make sense if they are followed by a lexical realization that is compatible with their meaning; that is to say, in tautologies of the type 'It is like a result; it has to happen after something else happens'.

When used with a metadiscursive value, the nouns studied frequently occur in two types of syntactic constructions; in identifying sentences such as (8) above: EI resultado es que el gobierno crece demasiado 'The result is that the government grows too much'; and in cleft or emphatic relative sentences (Kovacci 1992) such as (19):

(19) No hay una Ley de Asilo en Italia. [...]

Esa es la razón por la que se ha criticado que Italia, hasta hace sólo algunos meses, no haya ratificado el Protocolo de Nueva York de 1967, en relación con los refugiados. (López Garrido, Diego 1991. El derecho de asilo. Madrid: Trotta)

There is no Asylum Law in Italy. [...]

That is the reason why it has been criticized that Italy, until only a few months ago, had not ratified the 1967 New York Protocol in relation to refugees'

In (8), the argument that is the complement of resultado is implicit, since the relationship between the cause or causes that lead to this result are not expressed, but can be inferred from the context, i.e. it refers to the result of what has been previously mentioned. In this example (19), the demonstrative esa and the relative la que highlight and recover a previously mentioned Theme (No hay una Ley de Asilo en Italia) and therefore serve as cohesion markers of anaphoric reference.

\subsection{Grammaticalized locution pattern}

Finally, examples (20) to (23) below illustrate a further grammatical pattern which also proved to be highly productive in the corpus studied. In Spanish, the nouns studied are part of prepositional, conjunctive or adverbial locutions that function as lexical connectors or linking expressions:

(20) La dignidad como rango o categoría de la persona como tal, del que deriva y en el que se proyecta el derecho al honor (art. 18.1 CE), no admite discriminación alguna por razón de nacimiento, raza o sexo, opiniones o creencias [...]. (Atienza, Manuel 1993. Tras la justicia. Una introducción al derecho y al razonamiento jurídico. Barcelona: Ariel, p. 48)

'Dignity as a rank or category of the person as such, from which the right to honor is derived and in which it is projected (Art. 18.1 EC), admits no discrimination whatsoever by reason of birth, race or sex, opinions or beliefs.'

(21) [...] así es que basta en principio invocar un fundado temor a ser perseguido en su país de origen por motivo de raza, religión, nacionalidad, pertenencia a determinado grupo social o de opiniones políticas; [...] ((López Garrido, Diego 1991. El derecho de asilo. Madrid: Trotta)

'[...] therefore, in principle it is enough to invoke a grounded fear to be persecuted in his country of origin by reason of race, religion, nationality, belonging to a certain social group or to certain political opinions.'

(22) No basta con que haya miedo de ser implicado en violencias incidentales como resultado de disturbios civiles o locales... (López Garrido, Diego 1991. El derecho de asilo. Madrid: Trotta, p. 68) 
'The fear of being involved in incidental violence as a result of civil or local disturbances is not sufficient...'

(23) En esa discusión destacó la denominada 'Escuela de Salamanca', que en el siglo XVI formuló, por primera vez, la relación entre el aumento de la masa monetaria y el alza de los precios, como consecuencia de los fenómenos que se prodigaron a raíz de la entrada de los metales preciosos provenientes de América. (Tamames, Ramón 1992. Curso de Economía. Madrid: Alhambra Longman, p. 20)

'In that discussion, the so-called 'Salamanca School' was noteworthy; in the 16th century it formulated, for the first time, the relationship between the increase in the monetary mass and the rise in prices, as a consequence of the many phenomena resulting from the arrival of precious metals coming from America.'

In this pattern, the semiterms have been grammaticalized to the extent that the locutions can be exchangeable. In the same contexts, for example, como consecuencia $d e$ 'as a consequence of' and como resultado de 'as a result of' ${ }^{9}$ can alternate with each other. The most commonly recurring patterns in our corpus are the following:

- Prepositional locutions: preposition + noun + preposition: a consecuencia de 'as a consequence of'; a razón de 'at the rate of', con motivo de 'on the occasion of', por razón de 'by reason of', por motivo de 'due to', como resultado de 'as a result of', como consecuencia de 'as a consequence of'.

- Conjunctive locutions: preposition + noun + preposition + que: a consecuencia de (que) 'as a consequence of / the fact that', por razón de (que) 'due to / the fact that'.

- Adverbial locutions: en consecuencia 'in consequence', como consecuencia 'as a consequence'.

These patterns vary in their degree of fixedness ${ }^{10}$ : for example, the locution como (el) resultado de is less fixed than por razón de. The level of performance and the degree of autonomy they show in the discourse also vary: locutions such as como resultado de, como consecuencia de and a consecuencia de are syntactically integrated into the sentence while others show suprasentential or textual uses. This is the case of en consecuencia and como consecuencia, which constitute parenthetical connectors and are thus used between pauses or between commas, and exhibit greater syntactic autonomy. In descriptive grammars of Spanish, these instances are called consecutive connectors (Martín Zorraquino and Portolés 1999).

The use of the studied nouns as connectors can be said to represent the result of the semantic bleaching process described in metadiscursive patterns. From the terminological pattern to grammaticalized locutions, a process of grammaticalization may thus be established, as seen in Figure 5:

Figure 5. Process of grammaticalization of the semiterms

\begin{tabular}{llll}
\hline Pattern 1 & Pattern 2 & Pattern 3 \\
\hline term & $\begin{array}{l}\text { copulative emphatic structure or relative } \\
\text { periphrasis }\end{array}$ & $>$ grammaticalized locution \\
$\begin{array}{l}\text { resultados fiscales } \\
\text { 'fiscal results' }\end{array}$ & $\begin{array}{l}\text { El resultado es que } \\
\text { 'The result is that...' }\end{array}$ & $\begin{array}{l}\text { como resultado de } \\
\text { 'as a result of' }\end{array}$ \\
$\begin{array}{l}\text { razones de Estado } \\
\text { 'reasons of State' }\end{array}$ & $\begin{array}{l}\text { Estas son las razones fundamentales que... } \\
\text { 'These are the fundamental reasons that...' }\end{array}$ & $\begin{array}{l}\text { por razón de } \\
\text { 'by reason of' }\end{array}$ \\
\hline
\end{tabular}

A similar process applies to other Spanish discourse markers such as sin embargo 'however' or a pesar de 'in spite of', which are formed on the basis of a noun. 
The use of semiterms as grammaticalized units in more or less fixed phrases has not been studied in previous works about these lexical items. These nouns in Spanish language revealed to be very productive in fixed constructions as described in this section, in contrast with their uses in English.

\section{Quantitative findings}

In this section I will give the percentages of each pattern identified in this paper, according to the specialized field. Table 6 below presents the percentages of occurrence $^{11}$ of the five semiterms studied in each of the three patterns of use detailed in section 5: as multilexemic terminological (T) units, with metadiscursive $(\mathrm{M})$ value as discourse markers or as Focus or Theme signs, and as grammaticalized locutions (L) ${ }^{12}$.

Table 6. Percentages of occurrence of semiterms patterns ${ }^{11}$

$\mathrm{T}$ (term), M (marker of Focus or Theme), L (locution)

Science and Technology Economics and Finance Law

\begin{tabular}{|l|ccc|ccc|ccc|}
\cline { 2 - 9 } \multicolumn{1}{l|}{ Semiterms } & $\mathrm{T}$ & $\mathrm{M}$ & $\mathrm{L}$ & $\mathrm{T}$ & $\mathrm{M}$ & $\mathrm{L}$ & $\mathrm{T}$ & $\mathrm{M}$ & $\mathrm{L}$ \\
\hline $\begin{array}{l}\text { problema } \\
\text { 'problem' }\end{array}$ & $77.18 \%$ & $22.14 \%$ & $0.67 \%$ & $89 \%$ & $9 \%$ & - & $86.5 \%$ & $11 \%$ & $1 \%$ \\
$\begin{array}{l}\text { resultado } \\
\text { 'result' }\end{array}$ & $82.14 \%$ & $7.14 \%$ & $10.71 \%$ & $31.93 \%$ & $48.73 \%$ & $19.32 \%$ & $86.15 \%$ & $6.15 \%$ & $7.69 \%$ \\
$\begin{array}{l}\text { motivo } \\
\text { 'motive' }\end{array}$ & $21.05 \%$ & $42.10 \%$ & $36.84 \%$ & $66.66 \%$ & - & $33.33 \%$ & $72.38 \%$ & $19.04 \%$ & $8.57 \%$ \\
$\begin{array}{l}\text { razón } \\
\text { 'reason' }\end{array}$ & $27.58 \%$ & $62.06 \%$ & $10.34 \%$ & $37.36 \%$ & $31.86 \%$ & $30.76 \%$ & $47.5 \%$ & $21.5 \%$ & $31 \%$ \\
$\begin{array}{l}\text { consecuencia } \\
\text { 'consequence' }\end{array}$ & $62.5 \%$ & $11.36 \%$ & $26.13 \%$ & $27.22 \%$ & $14.13 \%$ & $58.63 \%$ & $44 \%$ & $13.5 \%$ & $42.5 \%$ \\
\hline
\end{tabular}

Of the five nouns analyzed, problema is the one that tends to be used more frequently with a terminological value in the three fields. Examples of this use have been presented in Table 5 above: problemas científicos, problemas económicos, problemas de inflación and problemas jurídicos. The high frequency of problema in terminological patterns may be due to the fact that, unlike the other nouns, it is not a relative noun.

The terminological use of resultado was also frequent in Science and Technology $(82.14 \%)$ and in Law (86.15\%), as in the examples shown in Table 5: resultados de la investigación, resultados científicos, resultado jurídico and resultado lesivo. On the other hand, in Economics and Finance, it is used more pragmatically to highlight the information as a metadiscursive marker in almost $50 \%$ of the cases $(48.73 \%)$, as in the pattern El resultado es que.

In the fields of Economics and Finance and especially Law the word motivo is frequently used in terminological combinations in phrases of the type exposición de motivos 'presentation of motives', and motivos jurídicos 'legal reasons'. On the other hand, in the Science and Technology texts, its most frequent occurrence is as a marker of Focus or Theme, as in Ese es el motivo por el que.

Finally, the word consecuencia was found to be the one most frequently used in grammaticalized locutions such as como consecuencia, en consecuencia and $a$ consecuencia de que, with frequencies ranging from approximately $26 \%$ in Science and Technology to almost $60 \%$ in Economics and Finance. Also frequently used in locutions 
were the semiterms motivo and razón: motivo is the most frequently used in Science and Technology (almost 37\%), whereas razón is the most frequently used in Law (31\%).

Comparison of our data across fields may also provide some information as to the type of discourse that characterizes each discipline. It must be noted, however, that the features that emerge from this analysis can only be interpreted as a cue of certain discursive characteristics and should be confirmed by further studies including other lexical items or linguistic devices that are beyond the scope of the present work. The discourse of Law appears to be more technical, since the nouns studied were most frequently used with a terminological value. This is the case of razón, motivo and resultado, which were found to be used with very specific meanings. On the other hand, the discourse of Science and Economics could be described as more explanatory, since it is structured by the frequent metadiscursive uses of the nouns studied.

\section{Summary and conclusions}

In sum, when used in specialized texts, the semiterms studied show characteristic syntactic and discursive behaviors. Specifically, the nouns problema, resultado, motivo, razón and consecuencia: a) show terminological uses to designate key disciplinary concepts; b) act as lexical markers of the argumentative structure of the texts; and c) participate in set phrases with connecting functions.

As we have observed, then, the semiterms studied can be used both at the local level of the phrase, clause or sentence and at the global level of the text to signal structure as lexical cohesive markers. At the local level they designate key concepts in the texts, whereas at the overall discourse level they highlight parts of the argumentative structure.

As for the interrelationship of the different levels of text analysis, that is to say, the level of the informational organization of discourse (in terms of Theme, Rheme and Focus), the syntactic level and the lexical level, it is important to note that the concept of pattern makes it possible to interrelate grammar and discourse. Two of the syntactic patterns included in this study, -on the one hand, identifying sentences; and on the other, cleft and emphatic relative sentences, both of them related to the metadiscursive function of semiterms-, are associated with two important pragmatic functions of discourse organization:

i) a metadiscursive function: semiterms take part in grammatical patterns that refer to previous or subsequent fragments of the discourse;

ii) focalization: semiterms form part of patterns that seek to highlight the information that contributes to the reader's stored knowledge.

These conclusions may contribute to grammatical explanations of why and when certain combinations and constructions are used. These findings may also be applicable to the teaching and learning of Spanish for specific purposes. Considering that the words analyzed are part of the general vocabulary, they are accessible to lay people and may offer pointers towards understanding and composing specialized texts. For this reason, it is proposed that these patterns should be incorporated into dictionaries of use (codifiers) as lexicographical data that may enrich the information given about these nouns, whose meanings are clearly diffuse.

\section{Notes}

1. These are termed thematic equatives in Halliday (1967) and identifying or equational sentences in descriptive grammar of Spanish (Fernández Ramírez 19851987). 
2. Words such as función 'function', estructura 'structure', sistema 'system', elemento 'element', unidad 'unit', and relación 'relationship' are also semiterms (Otañi 2005).

3. Occurrences are referred to as casos ('cases') in the RAE database.

4. As I have mentioned, the analysis of the most frequent combination patterns of the semiterms corresponds to the first 200 occurrences of each noun; the symbol $\Rightarrow$ used in table 3 means that I have considered only 200 concordance, although the RAE database offered a superior number of cases (223 cases, for example, for problema item in Economics and Finance).

5. The patterns of use of semiterms were classified by using three formal criteria, which are detailed below: 1) if they can be used with complements of textual anaphora; 2) if they can be metaphorized; and 3) if they omit the determiner el in grammaticalized uses. In future work, another rater will be used in order to compare the analysis.

6. In the examples presented here and below, bold is used to highlight words or word combinations that are discussed in the analysis. All translations in the examples are my own.

7. Cases in which the adjective or prepositional phrase is implicit were also considered.

8. Unlike the use of these nouns as terms, which can be metaphorized.

9. In Seco et al. 2004. Diccionario Fraseológico, como consecuencia de and como resultado de are given as phrases equivalent to a consecuencia de.

10. As stated by Pavón Lucero (1999: 581 et seq.), the following criteria can be established for the grammaticalization of (prepositional) locutions: [my translation]

a) The noun that forms part of a locution cannot be expanded into a noun phrase, i.e. the following are not admitted: an article or a demonstrative (*por esta razón de '*due to this reason of'); complementation (*como resultado jurídico de disturbios '*as a legal result of disturbances'; *a razón directa de 'directly due to'); quantifiers (*como muy / mucho resultado de '*as a very result of'); alternation in the noun complement of the preposition and the possessives $(a$ consecuencia de 'as a consequence of'; *a su consecuencia 'consequently'); a modifier between preposition-noun (*a consecuencia, sin embargo, de 'as a result, however, of'); and the noun is invariable as regards flexion (*como resultados directos de disturbios 'as direct results of disturbances').

b) They show a high degree of fixedness

c) They are internally linked forms

d) Their syntactic behavior is parallel to that of prepositions.

11. I use percentages instead of norm counts (Biber 1998) because I follow the number of cases the RAE database offers. In future work the counts are going to be normed to better compare the frequency of semiterms across fields and uses.

12. These uses are part of a continuum in which the boundaries are sometimes blurred: distinctions between the metadiscursive use and the grammaticalized use as a connector of a lexical unit are not always clearcut. For instance, in cases such as $l a$ balanza básica es (el) resultado / consecuencia / producto de integrar las mercancías ('the basic scale is the result / consequence / product of integrating the goods') the underlined words could be considered Focus markers. However, as it is possible to omit the determiner $e l$, we have considered them grammaticalized uses like como resultado de and como consecuencia de. 


\section{References}

Baker, M. 1988. 'Sub-technical vocabulary and the ESP teacher: an analysis of some rhetorical items in medical journal articles.' Reading in a Foreign Language 4/2: 91105.

Biber, D. 1996. 'Investigating language use through corpus-based analysis of association patterns.' International Journal of Corpus Linguistics 1/2: 171-198.

Biber, D. 2005. 'Paquetes léxicos en textos de estudio universitario: variación entre disciplinas académicas.' Revista Signos 57: 19-29 (published online: http://www.scielo.cl/scielo.php?script=sci arttext\&pid=S0718$\underline{09342005000100002 \& \operatorname{lng}=\mathrm{es} \text { ) }}$

Blaisten, N., L. Kornfeld, V. Mazer and M. E. Simoni. 2002. 'Caracterización del funcionamiento de los semitérminos en el vocabulario especializado' in Terminología, Desenvolvimiento e Identidades Nacional. Acts of the VI Simposio Iberoamericano de Terminología). Ediçoes Colibrí. (published online: http://www.riterm.net/actes/6simposio/blaisten.htm).

Bosque, I. 2004. Redes. Diccionario Combinatorio del Español Contemporáneo. SM.

Cabré, Ma . T. 1999. La Terminología: Representación y Comunicación. Elementos para una Teoría de Base Comunicativa y otros Artículos. Institut Universitari de Lingüística Aplicada.

Ciapuscio, G. 2003. Textos de Especialidad y Terminología. Institut Universitari de Lingüística Aplicada-Universitat Pompeu Fabra.

Conca, M., A. Costa, M'. J. Cuenca and G. Lluch. 1998. 'Els mecanismes de referència 'Els mecanismes gramaticals' in: Text i Gramàtica. Teoria i Pràctica de la Competència Comunicativa. Teide.

Cortes, V. 2008. 'A comparative analysis of lexical bundles in academic history writing in English and Spanish.' Corpora 3/1: 43-57.

Fernández Ramírez, S. 1985-1987. Gramática Española. 2nd edition redrafted, 5 volumes. Arco Libros (I: Prolegómenos; II: Los sonidos; III. 1: El nombre; III. 2: El pronombre; IV: El verbo y la oración. The first four prepared by José Polo; the last, by Ignacio Bosque). [1st edition: 1951. Los Sonidos, el Nombre y el Pronombre. Revista de Occidente].

Flowerdew, J. 2002. 'A pedagogic grammar of signalling nouns in discourse.' Revista Canaria de Estudios Ingleses 44: 141-155.

Flowerdew, J. 2003. 'Signalling nouns in discourse.' English for Specific Purposes 22: 329-346.

Francis, G. 1991. 'Nominal group heads and clause structure.' Word 42: 144-156.

Granger, S. 1998. 'Prefabricated patterns in advanced EFL writing: collocations and formulae' in Cowie, A.P. (ed.): Phraseology Theory, Analysis and Applications. Oxford University Press.

Halliday, M. A. K. 1967. 'Notes on transitivity and theme in English: II.' Journal of Linguistics 3/2: 199-244.

Halliday, M. A. K. and R. Hasan. 1976. Cohesion in English. Longman. 
Hanks, P. 2004. 'Corpus pattern analysis' in: Euralex 2004 Proceedings. Université de Bretagne Sud.

Hunston, S. 2001. 'Colligation, lexis, pattern, and text' in Scott, M. and G. Thompson (eds.): Patterns of Text. In Honour of Michael Hoey. John Benjamins Publishing Company.

Hunston, S. 2002. 'Pattern grammar, language teaching, and linguistic variation' in Reppen, Fitzmaurice and Biber (eds.).

Hunston, S. and G. Francis. 1999. Pattern Grammar. A Corpus-Driven Approach to the Lexical Grammar of English. John Benjamins Publishing Company.

Hyland, K. 2004. Disciplinary Discourses: Social Interactions in Academic Writing. University of Michigan Press.

Ivanič, R. 1991. 'Nouns in search of a context: a study of nouns with both open- and closed-system characteristics.' IRAL - International Review of Applied Linguistics in Language Teaching 29/2: 93-114.

Kovacci, O. 1992. 'Fórmulas sintácticas de relieve' in: El Comentario Gramatical. Teoría y Práctica, II. Arco/Libros.

López Ferrero, C. 2007. 'Patrones de tema y foco en los discursos de especialidad: esquemas sintácticos y vocabulario en español' in Kuteeva, M. and H. Fanha (eds.): Teaching and Learning LSP: Blurring Boundaries. Proceedings of the 6th International AELFE Conference.

Martín Zorraquino, Ma . A. and J. Portolés. 1999. 'Los marcadores del discurso' in Bosque, I. and V. Demonte (dirs.): Gramática Descriptiva de la Lengua Española. Espasa-Calpe.

Martínez, M. S. 1994. 'Spanish-English cognates in the subtechnical vocabulary found in engineering magazine texts.' English for Specific Purposes 13/1: 81-91.

Moon, R. 1998. Fixed Expressions and Idioms in English. Clarendon Press.

Nattinger, J. R. and J. S. DeCarrico. 1992. Lexical Phrases and Language Teaching. Oxford University Press.

Oakey, D. 2002. 'Formulaic language in English academic writing' in Reppen, Fitzmaurice and Biber (eds.).

Otañi, I. 2005. 'El papel de los semitérminos en los libros de texto' in: Acts of III Coloquio Nacional de Investigadores en Estudios del Discurso. (published online: http://www.fl.unc.edu.ar/aledar/hosted/3ercoloquio/534.pdf)

Partington, A. 1996. Patterns and Meanings. Using Corpora for English Language Research and Teaching. John Benjamins Publishing Company.

Pavón Lucero, Ma . V. 1999. 'Clases de partículas: preposición, conjunción y adverbio' in Bosque, I. and V. Demonte (eds.): Gramática Descriptiva de la Lengua Española. Espasa-Calpe.

Reppen, R., S.M. Fitzmaurice and D. Biber. 2002 (eds.): Using Corpora to Explore Linguistic Variation. John Benjamins Publishing Company.

Santos Río, L. 2003. Diccionario de Partículas. Luso-Española de Ediciones. 
Schmid, H.-J. 2000. English Abstract Nouns as Conceptual Shells. From Corpus to Cognition. Walter de Gruyter.

Scott, M. 2001.'Mapping key words to problem and solution' in Scott, M. and G. Thompson (eds.): Patterns of Text. In Honour of Michael Hoey. John Benjamins Publishing Company.

Seco, M., O. Andrés and G. Ramos. 2004. Diccionario Fraseológico Documentado del Español Actual. Aguilar.

Simpson, R. C. 2004. 'Stylistic features of academic speech: the role of formulaic expressions' in Connor, U. and T. A. Upton (eds.): Discourse in the Professions. Perspectives from Corpus Linguistics. John Benjamins Publishing Company.

Sinclair, J. 1991. Corpus Concordance Collocation. Oxford University Press.

Swales, J. 2001. 'Metatalk in American academic talk: the cases of point and thing'. Journal of English Linguistics 29/1: 34-54.

Tracy-Ventura, N., V. Cortes and D. Biber. 2007. 'Lexical bundles in speech and writing' in Parodi, P. (ed.): Working with Spanish Corpora. Continuum.

Trosborg, A. and P. E. Flyvholm Jørgensen. 2005. Business Discourse. Texts and Contexts. Peter Lang.

Wray, A. and M.R. Perkins. 2000. 'The functions of formulaic language: an integrated model.' Language and Communication 20: 1-28.

Winter, E. 1978. 'A look at the role of certain words in information structure' in Jones, K.P. and V. Horsnell (eds.): Informatics 3: Proceedings of a Conference Held by the Aslib Co-ordinate Indexing Group.

\section{Appendix: Criterion applied in data from CREA corpus}

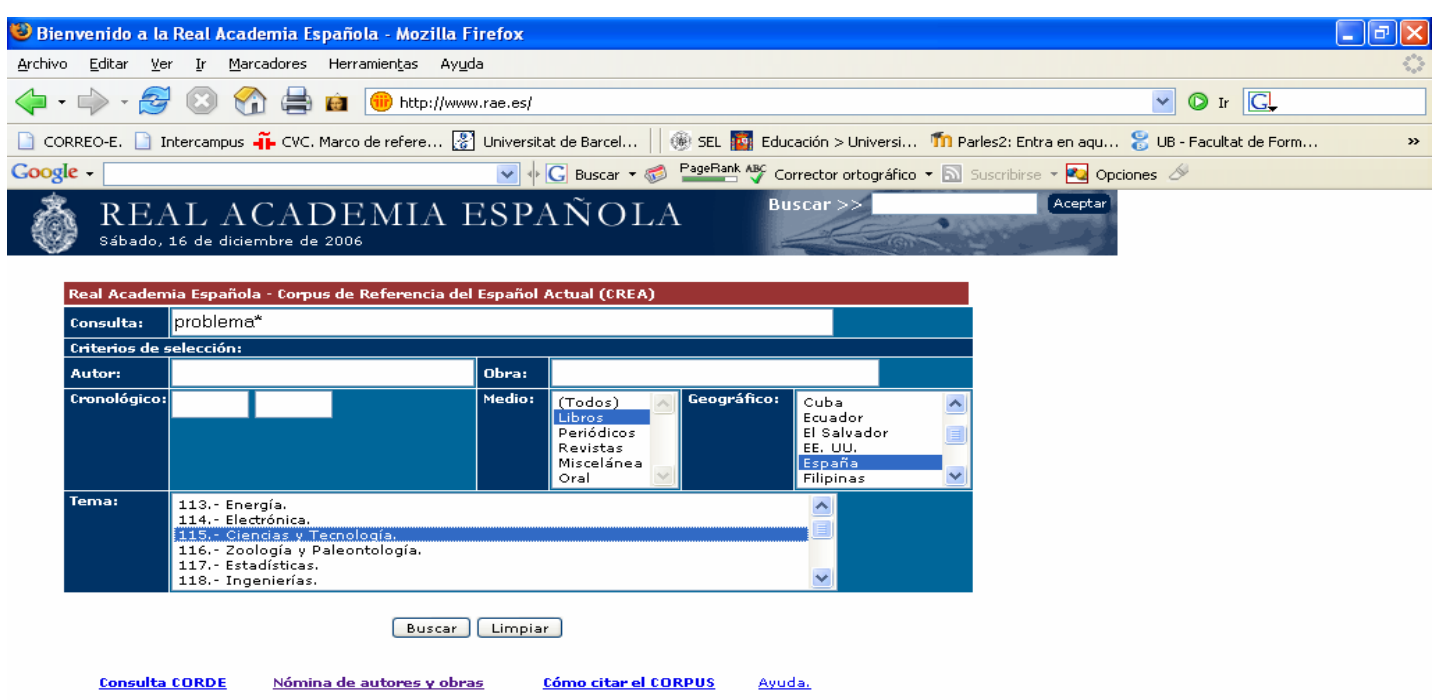

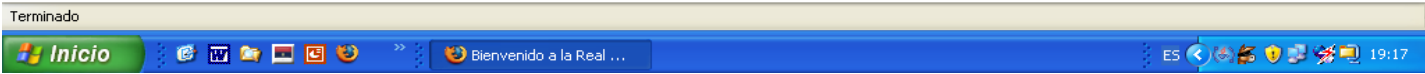

